\title{
THE RELATIONSHIP BETWEEN EMPLOYEES' PERCEPTION OF PERFORMANCE APPRAISAL AND WORK OUTCOMES
}

\author{
Senad Bušatlić \\ International University of Sarajevo, Faculty of Business Administration, Management \\ Sarajevo, Bosnia and Herzegovina \\ sbustalic@ius.edu.ba \\ Azra Musić - Kilic \\ Sarajevo, Bosnia and Herzegovina \\ azramusickilic@gmail.com
}

\begin{abstract}
Abstrakt
Human capital is of great importance for each organization that wants to fully achieve its goals. One of the key components of successful human resource management is performance appraisal process. The main aim of performance appraisal is to help employees eliminate performance deficiencies or encourage them to keep up with the good work, while in the same time aligning their performance with the organization's goals. Employees' perception of performance appraisal system is of high importance since it may affect their work outcomes. The purpose of this study is to analyse the effect of employees' perception of performance appraisal on their work performance, affective organizational commitment and turnover intention. Data were collected from 154 employees of small and medium enterprises in Bosnia and Herzegovina, area of research that is poorly explored. Results indicate that the relationship between employees' perception of performance appraisal and work performance, as well as affective organizational commitment, is positive with high to moderate degree of correlation, while the relationship with turnover intention is described as negative with moderate correlation.
\end{abstract}

Keywords: Performance appraisal, Work performance, Affective organizational commitment, Turnover intention, Human resource management.

\section{ODNOS IZMEĐU PERCEPCIJE ZAPOSLENIH O PROCENI PERFORMANSE I REZULTATA RADA}

\begin{abstract}
Ljudski kapital je od velikog značaja za svaku organizaciju koja želi u potpunosti ostvariti svoje ciljeve. Jedna od ključnih komponenti uspješnog upravljanja ljudskim resursima je procjena performansi. Glavni cilj procene performanse je pružanje podrške zaposlenima u smanjenju nedostataka u radu ili podsticanju na održavanje dobrog posla, istovremeno ujedno usklađivanje sa ciljevima organizacije. Percepcija zaposlenih o sistemu ocenjivanja performansi je od velikog značaja jer može uticati na njihove rezultate rada. Svrha ove studije je da analizira odnos između percepcija učinka zaposlenih i njihovog učinka, afektivne posvećenosti organizaciji i namere
\end{abstract}


prometa. Podaci su prikupljeni od 154 zaposlena u malim i srednjim preduzećima $u$ Bosni i Hercegovini, oblasti istraživanja koja je slabo istražena. Rezultati ukazuju na to da je odnos između percepcije zaposlenih o proceni učinka i performansi rada, kao i afektivnoj posvećenosti organizaciji, pozitivan sa visokim do umerenim stepenom korelacije, dok je odnos sa namerom prometa opisan kao negativan sa umerenom korelacijom.

Ključne reči: Ocenjivanje performanse, radni učinak, afektivna organizaciona posvećenost, intencija prometa, upravljanje ljudskim resursima.

\section{JEL code: L15, L19}

\section{INTRODUCTION}

The modern, dynamic world has brought challenges to organizations. The competitive scene requires from companies to be innovative and focused while developing the new strategies, because only though those, they can lower their costs and increase profit in an efficient manner. Based on the research studies evaluated by Dargham, the most successful organizations in the 21 st century will be the ones that will recognize the importance of human resource $(\mathrm{HR})$ professionals being involved in creating strategic plans [7].

Human resource management (HRM) focuses on personnel related areas such as resource planning, recruitment, selection, maintaining rights of employees, appraisal process, and compensations [10]. Out of all the areas mentioned, performance appraisal (PA) plays a central role in managing people, and it can be defined as evaluating and employee's current and past performance relative to his or her predefined performance standards [10]. The appraisal process cycle starts with defining the work standards, goes through the assessing the employee's actual performance, and ends with the feedback being articulated to the employee. The main aim of the PA is to help employees eliminate performance insufficiencies or encourage them to keep up with the good work, while in the same time aligning their performance with the organization's goals. Since the whole process is directly related to employees, it is expected that they tend to develop their own perception of performance appraisal. Prior studies have shown that employee's perception is an important factor in maintaining positive working environment and achieving satisfactory work outcomes [2]. According to Brown, Haytt, and Benson, the number of studies concerned with the relationship between employee's perception of performance appraisal and their work outcomes has increased, but in developing countries, such as Bosnia and Herzegovina, the research in this field in rather limited [6].

\subsection{PROBLEM STATEMENT}

Evaluating individual performance is a HRM task that should exist in every organization in order to better utilize operations. However, there are few employees and managers that have a positive attitude towards the appraisal process, and it is often considered as a perilous task [8]. According to Bekele, Shigutu, and Tensay, the reason for that is the possible subjective or irrelevant nature of the performance 
The relationship between employees' perception of performance appraisal and work outcomes

appraisal criteria such as shortage of skills and knowledge of the supervisors, favouritism, bias, and inability to deliver feedback on time [5]. Rahman and Shah stated that the success of any HR activity in an organization is dependent on employees' perception of that activity. If employees are satisfied with the implementation of performance appraisal, they will make effort to complete their job in the best possible way and it results in organization being more productive and successful [16]. If that is not the case, the consequences can be disastrous, both for individuals and organization itself. As reported in the work of Awosanya and Ademola, it is possible to predict the assessment response in relationship to job satisfaction and organizational commitment, because employees who are able to understand the performance appraisal system tend to behave in favour of organization [4]. The problem that arises directs the light toward examining the relationship between employee's perception of performance appraisal and work outcomes, that include work performance, organizational commitment, and turnover intention. According to Suliman's observation, work performance is shown through the accomplishment of allocated tasks, or as a result or consequence of action [19]. Employees that receive a timely feedback are more committed to work, so it is expected that their perception of performance appraisal will have positive relation to work performance $[17 ; 9 ; 19 ; 8 ; 5]$. Good HR practices result in increasing organizational effectiveness because employees tend to work harder in order to accomplish organizational goals when they are motivated. Individuals with positive view of being committed to an organization tend to see the organization's values as their own and eventually develop stronger commitment to the organization. Employees with high affective organizational commitment (AOC) tend to stay in the organization not because they have to, but because they simply want to. Positive appraisal system causes increase in employees understanding of his or her value and worth to the organizational team, and that results in higher commitment to the overall organizational objectives $[14 ; 19 ; 15 ; 5 ; 18]$. The third component of work outcomes is turnover intention, defined as a tendency of worker to change their working place in the labour market [10]. As Mustapha and Daud suggested, the effectiveness of a performance appraisal related to the turnover intention is overlooked and not well managed. The effect of employee's perception of performance appraisal on turnover intention has been disregarded by many researchers [12; 17; 3]. However, some of the previous studies suggest that the relationship between appraisal system and turnover intention exists, and it can be characterised as negative [19; $1 ; 15 ; 5]$. In Bosnia and Herzegovina, the importance of performance appraisal system is still not sufficiently studied. This study will enhance the understanding of performance appraisal and emphasize the importance it carries on employees' outcomes.

\subsection{RESEARCH QUESTION}

The main objective of this paper is to analyse the relationship between the employees' perception of performance appraisal and their work performance, affective organizational commitment and turnover intention. Based on the main objective of the research, the following question was addressed: 
1. Does the employees' perception of performance appraisal affect their work outcomes?

The main research question is supported by the following questions:

1. Is there a relationship between the employees' perception of performance appraisal and work performance?

2. Is there a relationship between the employees' perception of performance appraisal and affective organizational commitment?

3. Is there a relationship between the employees' perception of performance appraisal and turnover intention?

\subsection{RESEARCH HYPOTHESIS}

In order to satisfy the objective of the research and answer to the research question, on the basis of the related research evidence presented in the problem statement, the following hypotheses are stated:

H1. There is significant and positive relationship between employee's perception of performance appraisal and their work performance.

H2. There is significant and positive relationship between employee's perception of performance appraisal and their affective organizational commitment.

H3. There is significant and negative relationship between employee's perception of performance appraisal and their turnover intention.

\section{RESEARCH METHODOLOGY}

The research study was conducted using the principles of a cross-sectional study where data were collected across the population through sampling. The method of online questionnaire distribution was selected and conducted, thus enabling the collection of data from a greater number of public organizations in a given time and space. The quantitative research helps better examine the relationship between variables of the study, and the statistical methods to be used include: descriptive statistics - response frequency, reliability analysis - internal consistency of the questionnaire test, factor analysis -validity of instrument test, and correlation analysis - evaluating relationship between study variables.

\subsection{DATA COLLECTION AND SAMPLING METHOD}

The study was conducted among the employees of small and medium enterprises in Bosnia and Herzegovina. A simple sampling method was used in the data collection, in order to capture the general perspective of the employees' perception. 
The relationship between employees' perception of performance appraisal and work outcomes

Questionnaire was sent to employees via e-mail, using Google Forms application for collecting responses. The reason for choosing this collection technique is due to its wide geographic reachability and time limitation. In addition, distributing the questionnaire via e-mail, enabled the respondents to answer the questions at their pace. A cover letter was attached with the questionnaire in order to explain the objective of the study and encourage employees to participate in the study. The completion of the questionnaire was entirely voluntary and responses were anonymous. By accepting the mentioned terms, respondents would proceed with filling in the survey, giving permission to the researcher to use the data provided. The researcher maintained scientific objectivity throughout the study. Every person involved in the study was entitled to the right of privacy and dignity of treatment, and no personal harm was caused to the research subjects [19]. Data obtained were held in confidentiality, and the findings will be represented fairly and honestly, without intentional distortion.

A total of 181 responses were recorded. During the data processing, 27 questionnaire responses were excluded due to incomplete answers. The dependent variable of the study is work outcomes, that includes work performance, affective organizational commitment, and turnover intention. The independent variable of the study is employees' perception of performance appraisal.

\subsection{RESEARCH INSTRUMENT}

The research instrument - structured questionnaire was used to collect primary data. The adapted standardized instrument was used from study by Bekele et al. in 2014, so the pilot testing was not necessary. The questions were slightly modified for the scale of this research, in order to ensure applicability of the research instrument. The questionnaire was designed for collecting information on three variables: demographic, independent, and dependent. In the first part of the questionnaire that includes 6 questions, demographic characteristics of the respondents were collected gender, age, education level, working experience, job position, and working experience at the current position. The second and third part of the questionnaire consists of question statements used for the measuring study variables using 5-point Likert scale ( 1 - strongly disagree, 2 - disagree, 3 - neutral, 4 - agree, 5 - strongly agree). Therefore, respondents were able to specify level of agreement or disagreement with each specific statement. First 11 close-ended statements intended to measure employees' perception of performance appraisal. Following 23 statements aimed to measure employees' work outcomes ( 8 - work performance, 7 - affective organizational commitment, 8 - turnover intention).

\subsection{RELIABILITY TEST}

The reliability test helps us measure the error free rate of the research instrument. In addition, inter-item reliability should be measured as well in order to test the uniformity of respondents' responses to all items in a research instrument. The test 
used for measuring reliability of multipoint scaled items is the Cronbach's coefficient alpha test. An instrument that delivers a reliability coefficient of 0.70 and above is usually considered as a reliable one [5]. The overall variable reliability coefficients, as well as the inter-item coefficients, are presented in Table 1.

Table 1. Reliability coefficients

\begin{tabular}{|l|c|c|c|}
\hline Variable & Items & $\begin{array}{l}\text { Overall } \\
\text { Cronbach's Alpha }\end{array}$ & $\begin{array}{l}\text { Inter-item } \\
\text { Cronbach's Alpha }\end{array}$ \\
\hline Employees' perception of PA & 11 & .950 & $.941-.951$ \\
\hline Work performance organizational & 7 & .858 & $.827-.878$ \\
\hline $\begin{array}{l}\text { Affective } \\
\text { commitment }\end{array}$ & 8 & .873 & $.829-.920$ \\
\hline Turnover intention & 34 & .911 & $.882-.929$ \\
\hline Total & 884 & $.827-.951$ \\
\hline
\end{tabular}

Source: Author's compilation

\subsection{VALIDITY TEST}

Validity test is used to determine the extent to which data reflects accurately what it is meant to reflect. Out of three forms of validity - content, concurrent and construct validity, the first and third one are the most sophisticated and recommended for social studies [13]. The adapted questionnaire as an instrument is valid, but it is re-examined due to the adjustments made.

The factor analysis using principal component analysis is used to determine the eigenvalue and factor loading of each instrument's item. The main objective of this analysis is to determine whether the items in the questionnaire significantly contribute to the variables which they measure. The accepted criteria for factor analysis is when eigenvalue exceeds 1.0 and factor loading is greater than 0.30 [11]. As shown in Table 2 , the data for each variable loaded cleanly into one or two factors, with factor loading values exceeding 0.50 , so it can be concluded that the construct validity is satisfied.

Table 2. Construct validity analysis

\begin{tabular}{|l|c|c|c|c|}
\hline \multicolumn{1}{|c|}{ Variable } & Items & Components & Eigenvalue & $\begin{array}{c}\text { Factor } \\
\text { loading }\end{array}$ \\
\hline Employees' perception of PA & 11 & 1 & 7.342 & $66.74 \%$ \\
\hline Work performance organizational & 7 & 2 & 1.019 & $76.03 \%$ \\
\hline $\begin{array}{l}\text { Affective } \\
\text { commitment }\end{array}$ & 8 & 2 & 1.529 & $84.08 \%$ \\
\hline \begin{tabular}{l} 
Turnover intention \\
\hline
\end{tabular}
\end{tabular}

Source: Author's compilation 
The relationship between employees' perception of performance appraisal and work outcomes

The content validity is assessed using Kaiser-Meyer-Olkin (KMO) and Bartlett's test. KMO measures sampling adequacy and the values should be greater than 0.5 for all variables [11]. In addition, the Bartlett's test of sphericity and significance level results should maintain values $\mathrm{p}<0.001$ in order to reflect highly significant content validity.

Table 3. Content validity analysis

\begin{tabular}{|l|c|c|c|}
\hline \multicolumn{1}{|c|}{ Variable } & \multicolumn{1}{|c|}{$\begin{array}{c}\text { KMO (sam. } \\
\text { adequacy) }\end{array}$} & $\begin{array}{c}\text { Approx. Chi- } \\
\text { square }\end{array}$ & Sig. \\
\hline Employees' perception of PA & .932 & 1479.29 & .000 \\
\hline Work performance organizational & .857 & 557.46 & .000 \\
\hline $\begin{array}{l}\text { Affective } \\
\text { commitment }\end{array}$ & .868 & 686.45 & .000 \\
\hline Turnover intention & .886 & 1244.49 & .000 \\
\hline
\end{tabular}

Source: Author's compilation

\section{RESEARCH RESULTS}

The results of the empirical study are presented in light of the relationship between satisfaction with performance appraisal and work outcomes within the Bosnia and Herzegovina region. The findings are analysed based on the research objectives and hypotheses formed on the basis of previous studies' results.

\subsection{DESCRIPTIVE ANALYSIS}

The sample in the study were 154 individuals working in different SMEs of Bosnia and Herzegovina. Out of total accepted respondents, 93 were female, while the rest comprised of male respondents. Majority of respondents were from the middle age group between 25 and 44 years old (69.4 percent), younger group with age of less than 25 (27.3 percent), while only a small percentage was from older group (3.2 percent). Regarding the educational background, majority of participants were high-school diploma (41.6 percent) and bachelor diploma (39 percent) holders. The rest 19.5 percent individuals have completed their post-graduate studies. Almost three quarters of respondents are working at non-managerial positions, while 27.9 percent are different level managers (top, first line, middle line). Majority of the sample reported to be working at the organization between 1 and 7 years (50.6 percent) or less than 1 year (33.8 percent). This is followed by the ones working for more than 8 years at their current organization (15.6). Furthermore, 81.8 percent of total respondents noted that they have been working at their current position for less or equal to 5 years, while the remaining respondents have been working for more than 5 years.

In order to know the level of employees' perception of performance appraisal based on the responses, each item was analysed by comparing the standard deviation and 
mean score of each variable. The mean score below 3.39 is considered low, the score between 3.40 and 3.79 is moderate, and the one above 3.8 is high [11]. In the Table 4, the descriptive statistics of the variables is presented.

Table 4. Descriptive statistics

\begin{tabular}{|l|c|c|}
\hline Variable & Mean & Standard Deviation \\
\hline Employees' perception of PA & 3.59 & .955 \\
\hline Work performance & 4.04 & .665 \\
\hline Affective organizational commitment & 3.49 & .877 \\
\hline Turnover intention & 3.02 & 1.00 \\
\hline
\end{tabular}

Source: Author's compilation

Satisfaction with performance appraisal among the employees is moderate. Among the dependent variables, work performance was perceived to be the highest with mean of 4.04 and lowest standard deviation. Affective organizational commitment followed the mentioned variable with moderate perception, and turnover intention with low perception.

\subsection{CORRELATION ANALYSIS}

Correlation analysis is used to show the strength of the relationship between the independent variable and dependent variables. Inter-correlation coefficients were calculated using Pearson's r. which applies to variables distributed along ratio scales of measurement. Higher correlation value implies stronger relationship that can be either positive or negative. When the correlation is 0 , there is no relationship between variables. According to Cohen (as cited in Bekele et al), the correlation coefficient $r$ ranging from 0.10 to 0.29 indicated low degree of correlation, $r$ ranging from 0.30 to 0.49 represents moderate association, and $\mathrm{r}$ ranging from 0.50 to 1.00 may be considered as a high degree of correlation [5].

Table 5. Correlation matrix employees' perception of PA and work performance

\begin{tabular}{|l|l|c|c|}
\hline \multicolumn{1}{|c|}{ Variable } & $\begin{array}{c}\text { Employees' perception } \\
\text { of PA }\end{array}$ & $\begin{array}{c}\text { Work } \\
\text { performance }\end{array}$ \\
\hline $\begin{array}{l}\text { Employees' perception } \\
\text { of PA }\end{array}$ & Pearson's r & 1 & $.457^{* *}$ \\
\hline Work performance & Pearson's r & $.457^{* *}$ & 1 \\
\hline \multicolumn{2}{|l|}{ Significance } & .000 & .000 \\
\hline **. Correlation is significant at the 0.01 level (2-tailed) \\
\hline
\end{tabular}

Source: Author's compilation 
The relationship between employees' perception of performance appraisal and work outcomes

In order to test the first research hypothesis H1, the result of the correlation is analysed to show the strength of the relationship between the independent variable employees' perception of PA and dependent variable work performance. Table 5 presents the correlation coefficients of variables and the significance of relationship. Based on the analysis, the relationship between employees' perception of performance appraisal and work performance is positive and significant relationship of moderate degree. Therefore, the first hypothesis H1 is supported.

Table 6. Correlation matrix of employees' perception of PA and AOC

\begin{tabular}{|l|l|c|c|}
\hline \multicolumn{1}{|c|}{ Variable } & $\begin{array}{c}\text { Employees' perception } \\
\text { of PA }\end{array}$ & AOC \\
\hline $\begin{array}{l}\text { Employees' perception of } \\
\text { PA }\end{array}$ & Pearson's $r$ & 1 & $.656^{* *}$ \\
\hline AOC & Pearson's r & $.656^{* *}$ & 1 \\
\hline & Significance & .000 & .000 \\
\hline \multirow{2}{***}{. Correlation is significant at the 0.01 level (2-tailed) } \\
\hline
\end{tabular}

Source: Author's compilation

The second research hypothesis $\mathrm{H} 2$ is tested to show the correlation and the strength of the relationship between the independent variable employees' perception of PA and dependent variable affective organizational commitment. The results show that the relationship between employees' perception of performance appraisal and AOC is positive and significant with high degree of correlation. Therefore, the second hypothesis $\mathrm{H} 2$ is supported as well, and the results are shown in Table 6.

Table 7. Correlation matrix employees' perception of PA and turnover intention

\begin{tabular}{|l|l|c|c|}
\hline \multicolumn{1}{|c|}{ Variable } & $\begin{array}{c}\text { Employees' perception } \\
\text { of PA }\end{array}$ & $\begin{array}{c}\text { Turnover } \\
\text { intention }\end{array}$ \\
\hline $\begin{array}{l}\text { Employees' perception of } \\
\text { PA }\end{array}$ & Pearson's r & 1 & $-.373^{* *}$ \\
\hline Turnover intention & Pearson's $r$ & $-.373^{* *}$ & 1 \\
\hline \multicolumn{2}{|c|}{.000} & .000 \\
\hline \multirow{2}{*}{.*. Correlation is significant at the 0.01 level (2-tailed) } \\
\hline
\end{tabular}

Source: Author's compilation

The third hypothesis H3 is supported as well, since the correlation analysis indicates negative and significant relationship between employees' perception of PA and turnover intention, with the moderate degree of correlation. The results in Table 7 illustrate the Pearson's correlation coefficient and significance of relationship. 


\section{DISCUSSION AND CONCLUSION}

The research objective of the research was to explore relationships between employees' perception of performance appraisal and work outcomes that include work performance, affective organizational commitment and turnover intention. The results obtained indicate that employees' perception is positively related to work performance and affective organizational commitment, and negatively related to turnover intention. Number of previous studies presented positive and significant relationship between employees' perception of PA and work performance, yet their degree of correlation was lower than the one obtained in this research $[17 ; 9 ; 19 ; 8$; 5]. Moreover, positive and significant relationship between employees' perception of PA and AOC was stated by various studies, and the degrees of correlation are in the interval of being moderate and high $[14 ; 19 ; 15 ; 5 ; 18]$. Regarding the negative significant relationship between employees' perception of PA and turnover intention, number of studies reported low to moderate degree of correlation, while this study reports higher moderate correlation between the variables $[19 ; 1 ; 15 ; 5)$.

This study contributes to the overall research in the related field by providing additional empirical support on emphasizing importance of performance appraisal. Performance appraisal system in each organization should be implemented with special attention in order to make employee exert their efforts in the direction of implementation of organizational objectives and aims. In the situation where employees are not aware nor familiar with the steps in the expected performance, it is challenging to anticipate better work performance, organizational commitment and reduced turnover intention.

\section{REFERENCES}

1. Ahmad, R., Lemba, C., \& Ismai, W. (2010). Performance Appraisal Politics and Employee Turnover Intention. Journal Kemanrusiaan, (16), 99-109.

2. Ahmed, I., Mohammad, S., Ramzan, M., \& Islam, T. (2011). Relationship between Perceived Fariness in Performance Appraisal and OCB: Mediating Role of Organizational Commitment. International Journal of Academic Research, $3(5), 15-20$.

3. Alexander, N. (2012). The effects of perceived organizational support, perceived supervisor support and intra-organizational network resources on turnover intentions: A study of Chinese employees in multinational enterprises. Personnel Review, 41(1), $22-29$.

4. Awosanya, O. \& Ademola, O. (2007). Staff performance appraisal using fuzzy evaluation. International Federation for Information Processing, 247, 195-203.

5. Bekele, A., Shigutu, A., \& Tensay, A. (2014). The Effect of Employee's Perception of Performance Appraisal on Their Work Outcomes. International Journal of Management and Commerce Innovations, 2(1), 136-173.

6. Brown, M., Hyatt, D., \& Benson, J. (2010). Consequences of the performance appraisal experience. Personnel Review, 39(3), 375-396.

7. Dargham, S. (2010). Effective Management of the Performance Appraisal 
The relationship between employees' perception of performance appraisal and work outcomes

127

Process in Lebanon: An Exploratory Study. In Maître de Conferences a la FGM.

8. Dechev, Z. (2010). Effective Performance Appraisal - a study into the relation between employer satisfaction and optimizing business results (Master). Erasmus University Rotterdam.

9. DeNisi, A. S., \& Pritchard, R. D. (2006). Improving individual performance: A motivational framework. Management and Organization Review, 2, 253-277.

10. Dessler, G. (2015). Human resource management (1st ed.). Upper Saddle River, N.J.: Prentice Hall.

11. Field, A. (2005). Discovering Statistics using SPSS (2nd ed.). SAGE publication, Great Britain.

12. Huselid, M. A. (1995). The impact of human resource management practices on turnover, productivity and corporate financial performance. Academy of Management Journal, 38, 635-72.

13. Koigi, A. N. (2011). Improving organizational effectiveness of public enterprise in Kenya (Doctoral dissertation). Nelson Mandela Metropolitan University.

14. Levy, P. E., \& Williams, J. R. (2004). The social context of performance appraisal: A review and framework for the future. Journal of Management, 30, 881-905.

15. Mustapha, M., \& Daud, N. (2013). Perceived Performance Appraisal Effectiveness and Turnover Intention of Knowledge Workers: A Conceptual Model. Interdisciplinary Journal of Contemporary Research in Business, 5(7), 11-38.

16. Rahman, W., \& Shah, B. (2012). The mediating effects of perceived employee development on the relationships between performance appraisal and job performance in public universities of Khyber Pakhtunkhwa, Pakistan. Business and Management Review, 2(1), 11-26.

17. Rees, W. D., \& Porter, C. (2004). Appraisal pitfalls and training implications Part 2, Industrial and Commercial Training, 36(1), 29-34.

18. Singh, S., \& Rana, S. (2015). The impact of performance appraisal on organizational commitment of bank employees. International Journal of Science and Research, 4(4), 2964-67.

19. Vignaswaran, R. (2008). The Relationship between Performance Appraisal Satisfaction and Employee Outcomes: A study conducted in peninsular Malaysia (Master). University of Malaya.

\section{REZIME}

Istraživački cilj istraživanja bio je da se istraže odnosi između percepcije zaposlenih o proceni učinka i ishoda rada koji uključuju radne performanse, afektivnu organizacionu posvećenost i namjenu prometa. Dobijeni rezultati ukazuju na to da je percepcija zaposlenih pozitivno povezana sa radnim učincima i afektivnim organizacijskim obavezama, a negativno je povezana sa namerom prometa. Broj prethodnih studija pokazao je pozitivan i značajan odnos između percepcije zaposlenih i radnog učinka zaposlenih, a njihov stepen korelacije je bio niži nego što 
je dobijen u ovom istraživanju $[17 ; 9 ; 19 ; 8 ; 5]$. Štaviše, pozitivni i značajni odnosi između percepcije zaposlenih prema PA i AOC-u su utvrđeni različitim studijama, a stepen korelacije je u intervalu umerenog i visokog $[14 ; 19 ; 15 ; 5 ; 18]$. U odnosu na negativan značajan odnos između percepcije zaposlenih i namjene prometa, broj studija je pokazao nizak do umjereni stepen korelacije, dok ova studija prikazuje veću umerenu korelaciju između varijabli $[19 ; 1 ; 15 ; 5)$.

Ova studija doprinosi ukupnom istraživanju u srodnoj oblasti pružanjem dodatne empirijske podrške u naglasivanju važnosti procjene učinka. Sistem procene učinka u svakoj organizaciji treba provesti sa posebnom pažnjom kako bi zaposleni učinio svoje napore u pravcu ostvarivanja organizacionih ciljeva i ciljeva. U situaciji kada zaposleni nisu upoznati ni upoznati sa koracima u očekivanom učinku, teško je predvidjeti bolje radne performanse, posvećenost organizaciji i smanjenu namjenu prometa. 